\section{International spaceports planned for northern Australia}

\section{Sydney}

Australia is to be the site for an international spaceport, if the governments in the top end of the continent have their way. A A $\$ 93,000$ study commissioned by the Queensland state government is to recommend that at least $2,000 \mathrm{~km}^{2}$ be set aside for a spaceport on the Cape York Peninsula, Australia's northernmost tip.

The size of the area is to allow plenty of space for horizontal take-off and landing rocketships, such as the British HOTOL or West German Sanger projects. Cape York is a vast and virtually unpopulated area near to the equator, at a latitude of $12^{\circ} \mathrm{S}$ and is close enough for rockets launched there to take full advantage of the boost provided by the Earth's spin.

The same applies to the north coast of the Northern Territory. Having been prompted to consider the benefits of a spaceport, the Northern Territory government has dusted off a 1965 report by the European Launcher Development Organization (ELDO) which recommended a launch site near Darwin. A committee is reviewing the conclusions of the ELDO study to see if they are still valid today.

Both governments hope to attract launch operators from around the world. They consider that US rocket manufacturers will be moving into the launch business now that NASA is no longer launching commercial satellites.

The west Pacific location should be particularly attractive to Japan whose only launch sites are 30 degrees off the equator and closed for 10 months a year to placate local fishermen. They are also looking hopefully towards China whose only launch site at present is 40 degrees from the equator. The Queensland study is being conducted for Australia's Institution of Engineers by representatives of Hawker De Havilland, British Aerospace Australia, the University of Queensland, AUSSAT (the company operating Australia's domestic communication satellites), and the Commonwealth Scientific and Industrial Organization.

According to Mr Stan Schaetzel, leader of the study group and technical director at Hawker De Havilland, the report will recommend a site on the western side of Cape York facing the Gulf of Carpentaria. One great advantage of this site is its access to a variety of orbits without needing to overfly any centres of population. A standard due east launch would carry the rocket over the uninhabited forests of Cape York then out over the Pacific. For a polar orbit the rocket would head SSW, flying down over the Gulf of Carpentaria, across the continent and out over the Southern Ocean on a heading for the
South Pole. Spent first-stage boosters would crash into the Simpson Desert somewhere to the east of Alice Springs. A course across Cape York and closer to the Queensland coast gives the spaceport access to a $28.5^{\circ}$ orbit which corresponds to a due-east launch from Cape Kennedy and is the orbit NASA's space station will occupy. The US spaceports have very poor access to some orbits. Polar orbits cannot be reached from Cape Kennedy without wasting a lot of energy, whereas the other US launch facility at Vandenberg Airforce Base in California can launch into orbits but not due-east. Schaetzel points out that the US space agenda announced in 1986 calls for the establishment of a Moon base by 2010 . The $28.5^{\circ}$ orbit may well grow in importance in terms of the space station and space-based manufacture and for missions to the Moon and beyond.

Cape York's climate is favourable; only 39 launch days would be lost to electrical storms each year compared to 57 days lost I'd still rather have the

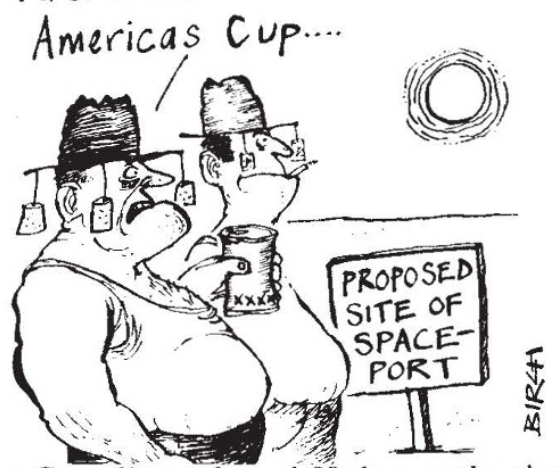
at Cape Kennedy and 89 days at the site run by the European Space Agency (ESA) at Kourou in French Guyana, at present the only equatorial launch site.

Provision of infrastructure in such a remote part of Austalia is simplified by the fact that the prospective spaceport is right alongside what are perhaps the world's largest bauxite deposits. A nearby port capable of handling ships of up to 75,000 tonnes was built by Comalco Aluminium to support the workers at its mine there. Australia can also offer good radar cover and air traffic control as well as guaranteed political stability.

The world can be thought of as being divided into a land hemisphere and a water hemisphere. At present, all the world's launch sites are in the land hemisphere. Australia is in the water hemisphere. According to Schaetzel, at very least Australia an expect to play host to a spaceport which provides the pilots of future landing site.
Charles Morgan generations of shuttles with an emergency

\section{Far Eastern Science Centre performs badly}

\section{London}

THE Far Eastern Science Centre of the Soviet Academy of Sciences, founded in 1970 as a focus for scientific and technical progress on the Soviet Pacific Coast is not living up to expectations, according to Pravda. Academician Skryabin, the academic secretary of the Soviet Academy of Sciences, blames the "sickness" of the centre on the lack of adequate "cadres" but locals (and Pravda's Vladivostok correspondent, N. Bratchikov) say the distance from the academy's headquarters in Moscow makes proper control difficult.

New institutes of the Far Eastern Science Centre are built extremely slowly, and when completed, frequently stand unoccupied for lack of equipment. Only about 30-50 per cent of resources allocated are actually applied to work for the centre. The situation, bad in Vladivostok, is even worse in the outlying establishments of the centre. Laboratories, libraries and a computer centre specified in the plans have not been built. Furthermore, although some 9,500 staff (including 2,400 scientists) are now employed the number should be twice that. But the centre cannot attract qualified and motivated personnel until proper services are provided. At present 2,500 employees of the Far Eastern Science Centre are waiting for apartments and there are no hospitals, kindergartens or leisure facilities. The institutes do not solve such problems, nor do they provide proper working conditions. Laboratory space is only two-thirds of that given to a scientist at the Siberian Branch of the Academy in Novosibirsk, and allocations for instruments and equipment are only about half those at Novosibirsk.

In the mid-1970s, the centre was cited as an example of slackness in outlying scientific establishments. Mr Mikhail Gorbachev's recent visit to the Far East, where he repeated his calls for "restructuring", and "openness" has focused attention once again on the defects of the centre. However, the centre can claim a sound research record in many fields, especially Earth sciences, oceanology and ichthyology; its Kamchatka vulcanology centre is a world leader.

But the scientists say that if they are to do a proper job the centre should be converted into a Far Eastern branch of the academy (analogous to the Siberian branch) with an autonomous presidium, it should have a "worthy" material and technical base, and, while the planned new institutes should be built, the existing institutes should be properly equipped and staffed.

Vera Rich 